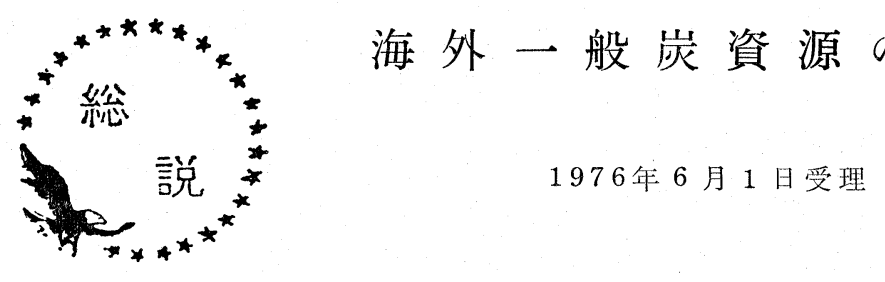

海外石炭開発(株) 調査部

\section{1. 緒 言}

新しいエネルギー情勢のもとで安定エネルギー資源 として石炭見直しの機運が急速に高末っている。石油 依存度の低下, エネルギーの多様化分散化を推進する ためには, 貴重な国内エネルギー資源である石炭は こんごとも，その生産の維持を図るとともに，国内 需要の不足分は海外各地に広く大量に賦存している 石炭の開発輸入を計画的に促進することが必要であ る。

こんご電源多様化の見地から新設される石炭火力の 燃料として, 一般炭の輸入は増加し昭和 55 年には約 500 万 $\mathrm{t}$, 同60年には 1,500 万 $\mathrm{t}$ 程度に達する見达み である。これらの石炭を長期にわたり安定的かつ効率 的に輸入していくためには, 資源保有国の現状と将来 計画を把握することが必要である。しかしながらわ が国は原料炭については従来から大量に輸入している ので, その情報は豊富であるが, 一般炭に関する情報 資料は不足しているのが現状である。

海外石炭開発(株)は通商産業省の昭和 50 年度海外炭 開発可能性調査費補助金の交付を受けて, 海外一般炭 に関する一般情報の収集, 操業状況の調查, 将来の開 発計画和よび開発可能性の調査を行なうこととなり, 石炭各社の協力を得てオーストラリア, アメリカ, ア フリカ,インドの 4 か国に調査団を派遣した。

これらの調查結果にもとずいて, 前記諸国に和ける 一般炭資源の概要を報告する。

\section{2. 各国の摡要}

\section{1 オーストラリア}

オーストラリアの主要産炭地であるニューサウスウ エールズ (NSW) とクインスランド (QLD) の両州 に持ける現行稼行炭鉙 17 , 新規プロジェクト13につい て操業状況, 将来の開発計画和よび開発可能性とあわ せて輸出のための港沙施設状沉を調查した。

\section{1 .1 埋藏炭量}

NSW 州では地質調査により最近の確定, 推定炭量

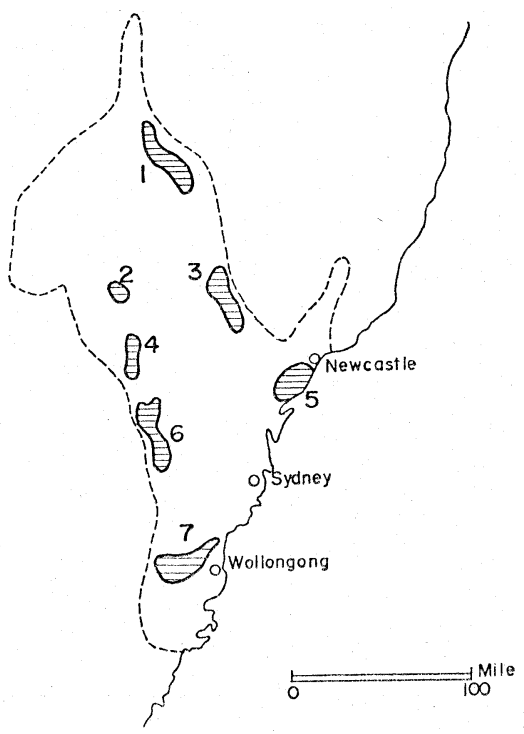
1. Gunnedah 2. Ulan
3. Muswellbrook-Singleton
4. Kandos 5. East Maitland
6. Lithgow 7. South Coast

図 1 オーストラリア N.S.W 州

として考兄らるのは 300 億 $\mathrm{t}$ であり, この 3 分の 1 にあたる 100億 $\mathrm{t}$ が一般炭である。またこの 100 億 $\mathrm{t}$ の一般炭のらち 20 億 $\mathrm{t}$ が露天掘り, 80 億 $\mathrm{t}$ が坑内掘 りによる採掘対象炭量である。

QLD 州に持汗る一般炭の確定, 推定炭量は 55 億 4, 500 万 $\mathrm{t}$ であり，このらち $80 \%$ が露天掘り，20\% が坑内掘りによる対象炭量であり, こんごの調查の進 屡により增加が考えられる。

\section{1 .2 炭質}

NSW 州捻よび QLD 州で考えられる一般炭の性質 としては，一般的に揮発分が $30 \%$ 以上, 硫黄分が 0.6 〜 $0.7 \%$, 灰分は 9.5 25\% 程度のものである。この らち輸出用として共同石炭庁が考光ている NSW 州の 
表 1 New South Wales の輸出向一般炭代表資料

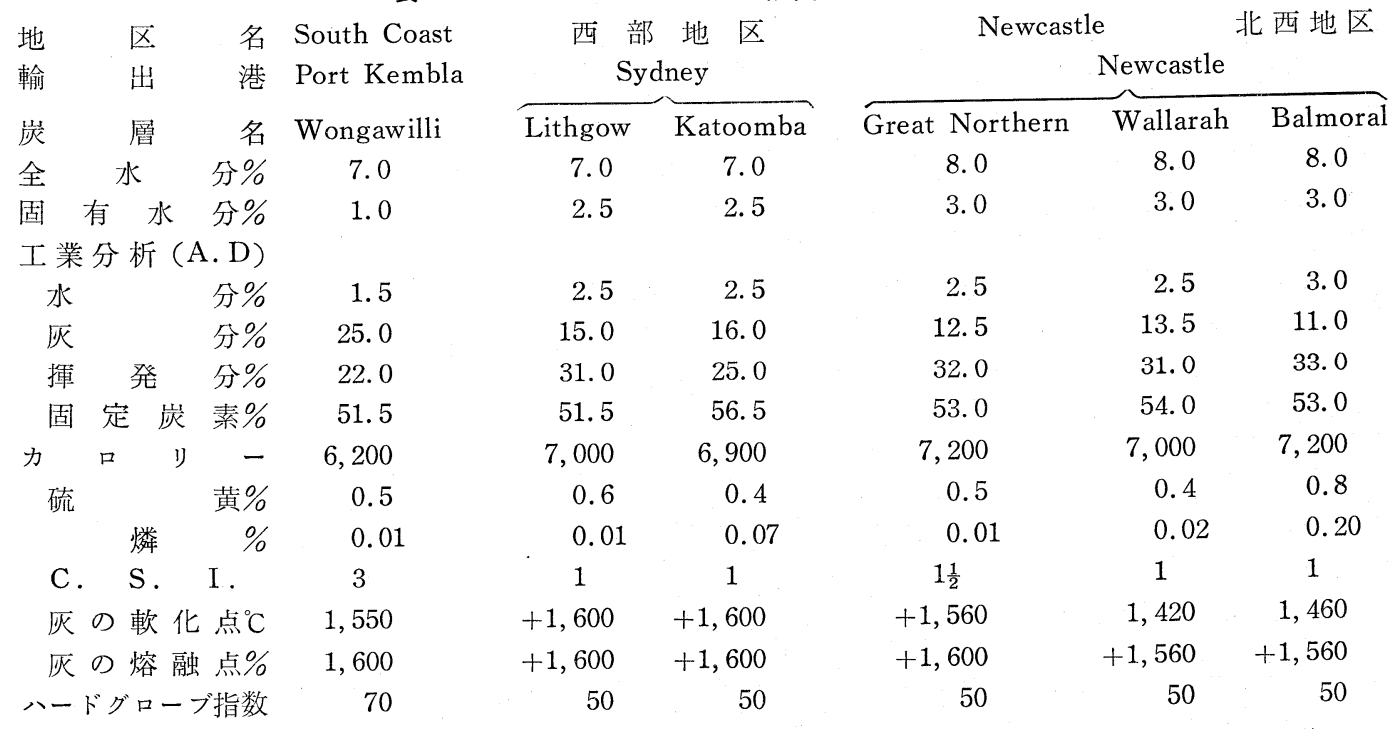

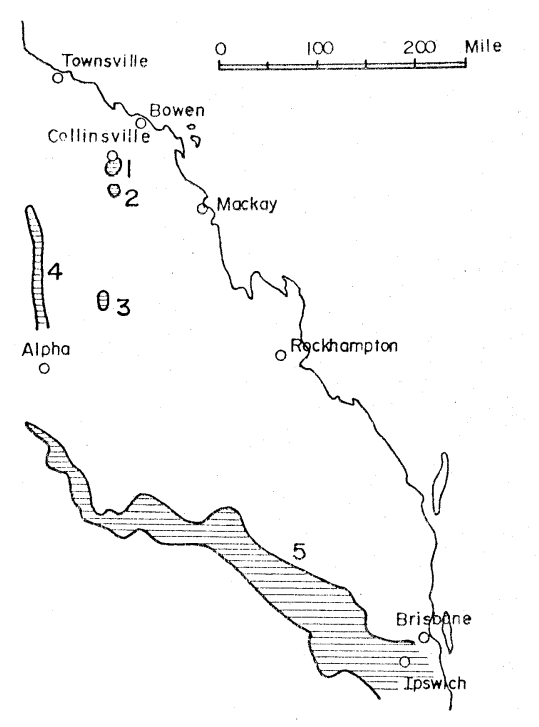

I. Bowen (Collinsville)

2. Newlands

3. Brair Athol

4. Galilee

5. Ipswich (Daring Down. Moreton)

図 2 オーストラリア QLD 州

\section{一般炭の性質は表 1 に示すものである。}

\section{1 .3 生産状沉}

オーストラリアに拈ける 1973 年度（1973年7月一 1974年 6 月) の石炭生産量 5,960 万

QLD 両州では 95.3\%を占めて括る。

$$
\text { N SW州 QLD州 }
$$

$\begin{array}{ccccc} & \text { 数量 } & \text { 比率 } & \text { 数量 } & \text { 比率 } \\ \text { 坑内掘 } & 30,155 & 82 & 3,483 & 17 \\ \text { 露天掘 } & 6,477 & 18 & 16,541 & 83 \\ \text { 計 } & 36,632 & 100 & 20,024 & 100\end{array}$

(数量単位, $1,000 \mathrm{t}$ )

このうち一般炭生産量は NSW 州で約 1,400 万 $\mathrm{t}$, QLD 州は約 400万 $\mathrm{t}$ で合計 1,800 万 $\mathrm{t}$ である。

NSW 州では坑内掘り $82 \%$, 露天掘り $18 \%$ であ り，坑内採炭方式としてはコンティニアスマイナーが $93 \%$, ロングオールが $2 \sim 3 \%$, カッター, 発破, 口 一ダー採炭が 4 〜 \% である。

QLD 州では坑内掘り $17 \%$, 露天掘り $83 \%$ であ り，坑内採炭方式のほとんどは柱房式である。

2.1 .4 一般炭の輸出状況

オーストラリアは海外へ一般炭を輸出しているが, それは主として電力, セメント用炭であり, 1974年よ りニューキャッスル港からの輸出が増加している。石 炭の海外輸出に対しては民間の石炭会社が個別に輸出 している。一般炭については生産を行なっている会社 がそれぞれ将来の増産計画を持って和り, 海外への輸 出を熱望している。しかし現状では港の積出能力に余 裕が少ないので1977年のニューキャッスル新ローダー の完成までは大量の一般炭輸出は困難であると考えら れる。

港の計画としては, ニューキャッスル港は1976年ま 
でに新港が完成の予定であり、ニューキャッスル地区 の石炭が主として先ず海外輸出に応ぜられるであろ う。な敃，その他の港についても契約量が増加すると 積出能力は限界一杯となるので, 政府の意向としては ポートケンブラ, ボタニベイ新港の建設が推進される であらう。

一般炭の輸出飞対しては個々の交涉は民間の石炭業 者に招いて進められているが，それぞれの業者が新鉱 を開発し，輸出する場合は連邦政府からエクスポート ライセンスの承認を受けなければならない。

\section{1 .5 新鉱開発時の承認事項}

\section{a) 承認について}

新鉱を開発しょうとする業者は共同石炭庁に対し (1)地質構造 (2)採掘計画 (3)石炭の販売 (4)鉄道港湾 関係 (5)環境問題 (6)財政その他などの計画の細部 にわたる情報を提出しなけ就ばならない。前記の情報 により共同石炭庁が判断する。

b) 輸出について

輸出については鉱物エネルギー省に契約, 数量, 価 格, 輸出先を提出し承認を受ける。

c) 採掘権について

採掘権については鉱山局が承認する。

d) 環境問題について

環境問題切ては環境庁とローカル・オーソリテ ィーの許可を得なければならない。

2.1 .6 所見

a) 炭 質

今回, 共同石炭庁から海外輸出用として提出された NSW 州の主要炭層の炭質, 各調查炭鉱に括汗る調査 結果蛙よび現地で採取した石炭試料のわが国での分析 結果などから総合的に判断すると，オーストラリア の一般炭の炭質としては灭分が $11 〜 16 \%$ ，発熱量は $6,200 \sim 7,200 \mathrm{cal}$, 硫黄分は $0.4 \sim 0.8 \%$, FSI は 1〜 $1 \frac{1}{2}$, 灰の熔融点は $1,420 \sim 1,600^{\circ} \mathrm{C}$ であり日本への輸 出を考觉ると良好な炭質であると判断さ机る。

b) 炭 量

共同石炭庁, QLD 石炭庁で発表された一般炭の現 状に和沙る確定, 推定炭量は NSW 州で 100 億 $\mathrm{t}$,

QLD 州では 55億4,500万 $\mathrm{t}$ であるが，今回雨州に拉 ける現地調查の結果では十分にこの炭量は㟧ることが 確認された。特に QLD 州飞特いては目下のところ 調查不十分では岁るが予想炭量は莫大溹るるのと判 断さ机る。前記炭量のらち NSW 州では 20\%, QLD 州では $80 \%$ 以上がそれぞれ露天掘り地より採掘でき る炭量で嵅り，その賦存状沉も良好で高いポテンシャ
ルがあるるのと考觉られる。

c) 採掘条件

炭層は比較的地表から浅い所㥛めて安定した状態 で赋存して特り，露天掘りにより採掘でさる部分が多 く，剝土比10以下で採掘が可能で贫り採掘条件は良好 で㐫る。坑内掘りの地域についてるガス, 水は少なく 上下盤は良好で山り稼行深度も浅く採掘条件は同㥞化 良好である。亦た坑内掘りで軟い泥岩の天盤，湖底採 掘, 夾夕の多い炭層の採掘などについてる日本の採掘 技術の適用により経済的な採掘が可能で亦る。

d) 生産コス卜

前記の採掘条件下での生産コストは他のソースに比 較して低く, 露天掘りの生産コストは特に低い。坑内 掘りについて子原料炭の採掘区域に比較して採掘条件 は良好で岾り，より低い原価で生産されているものと 判断される。

将来の開発が予想される区域についても現状と採掘 条件はほとんぞ差異がなく低コストでの生産が可能で 屴る。

e）石岸の輸送

一般炭の内陸輸送については㴗とんどの炭鈗が港か ら近く，大型貨車の採用などを必要とするの久で鉄道 の新設などを必要としないので輸送費も比較的低いと 考觉られる。

港については現状では原料炭の契約量に押されて余 裕はないが、ニューキャッスル新港が1976年末に建設 されることになって招り，他の港についても拡張また は新港の建設計画が㭊り, 海外からの一般炭の必要量 が強まれば港の建設を行なら余地は十分に专ると判断 される。

\section{f ) 生産規模}

生産規模については露天掘りと坑内掘りの区域では 現状に和いても元の生産量に大きな差異があるが, 将 来の開発規模としては 1 炭鉱当り露天掘り年産 200 万 $\mathrm{t}$, 坑内掘り年産 100 万 $\mathrm{t}$ 程度の規模で開発を計画 し, その組合せたょり日本への安定供給を図るべきで あろう。

\section{$g ）$ 将来の開発の可能性}

今回の調查は現行の稼行炭鉱, 新規プロジェクト抒 よび将来の有望区域について行店ったが, 現稼行炭鉣 からの增産の可能性として年間 700 万 $\mathrm{t}$, 新規プロジ エクトに上るものが年間 2,450 万 $\mathrm{t}$ と見込まれるので ポテンシャルは極めて高い。さらに将来の有望区域に ついても相当のポランンャルを有している。

したがってオーストラリアの一般炭は極就いポ 


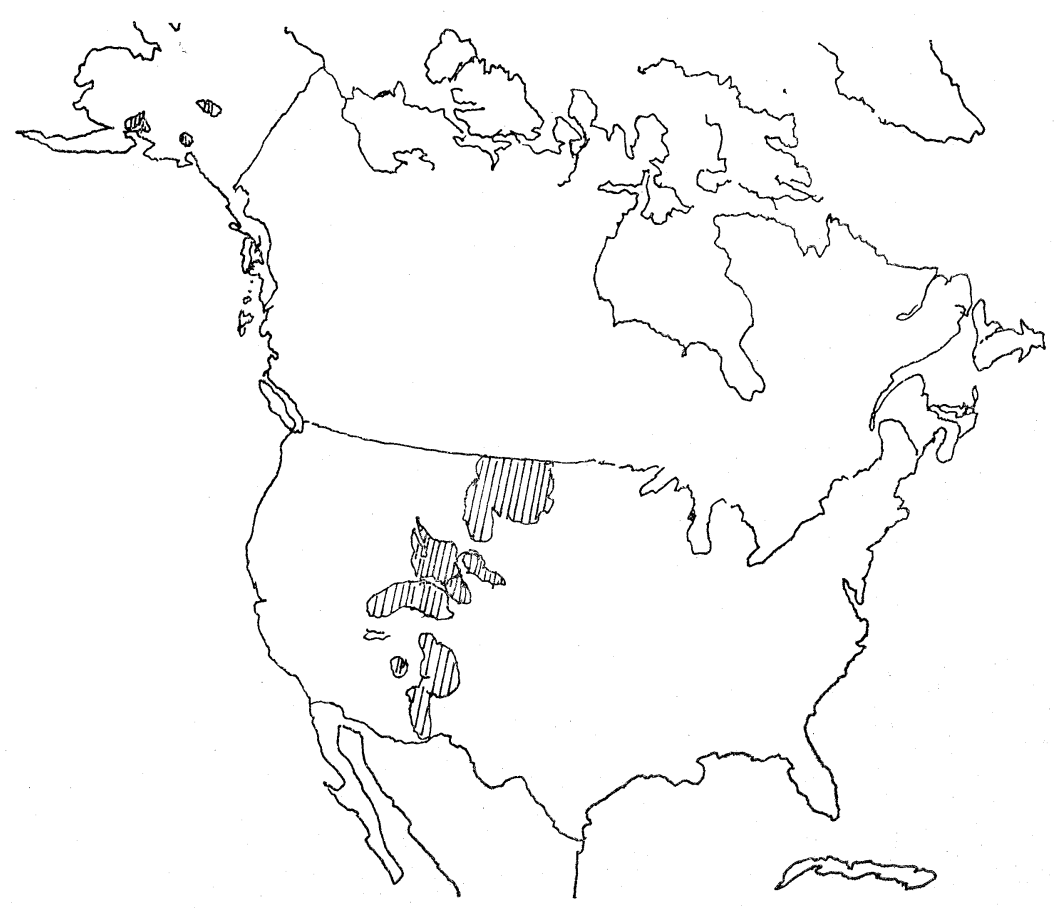

図3アメリカ対象地区

テンシャルを有し, 将来日本への安定供給の面では最 も有望なりースと考兑られる。

2.2 アメリカ

アラスカおよび中西部のらちニューメキシコ，コロ ラド，ワイオミング，ユタ，ノースダコダ，モンタナ の 6 州で稼行中の 8 炭鉱と新規プロジェクトの 6 区域 に括汗る一般炭の地質, 採掘条件, 学働, 石炭積出港 の施設および石炭に関する鉱業権，露天掘りに対する 環境保全の法的規制を調查し，将来の対日一般炭輸出 のソースとなるか否かの判断の基礎資料を収集し， わせて将来の開発輸入対象プロジェクトの採掘可能性 について調査した。

\section{2 .1 埋藏炭量}

アメリカ50州のらち，炭田を有する州は37州であり アラスカと西部 9 州はアメリカの主要炭田 区域であ る。

1972年のアメリカの総埋蔵炭量は 1 兆 5,542 億 $\mathrm{t}$ で あり，このらち アラスカと西部 9 州の合計は 1 兆 183 億 $\mathrm{t}$ ですり $66 \%$ を占めている。

炭種別にみると歴青炭と無煙炭が $15 \%$, 亜歴青炭が $42 \%$ ，かつ炭が $43 \%$ であり低品位炭が $85 \%$ を占め ている。アメリカの総埋蔵炭量のうち亜歷青炭, かつ
炭のほとんぞがこの地域に賦存して呿り，歴青炭は約 $20 \%$ がこの地域で，残り $80 \%$ は東部地域に主とし て賦存している。

1968年の露天掘可採埋蔵炭量はアメリカ 28 州で 450 億 $\mathrm{t}$, このらち歴青炭は 136億 $\mathrm{t}$, 亜歴青炭は 243 億 $\mathrm{t}$, かつ炭が 71 億 $\mathrm{t}$ である。のうちアラスカと西 部 9 州には歴青炭が $8 \%$ (11億 $\mathrm{t}$ ), 亜歴青炭が ほぼ 100\%（243億 $\mathrm{t}$ )，かつ炭が約 80\%（57億 $\mathrm{t}$ ）を占め て和り, 全アメリカ露天掘可採埋蔵炭量飞対して70\% （311億 t ）がこの地域に賦存している。

アラスカと西部 9 州の炭種別比率は歴青炭 $4 \%$, 亜 歷青炭78\%，かつ炭 $18 \%$ となる。また硫黄分 1\% 未満の低硫黄炭は約 $90 \%$ を占めている。

\section{2 .2 生産状況}

アラスカと西部諸州の歴青炭とかつ炭の1974年生産 量は 75,878千tであり, アメリカ総生産量の601百万 $\mathrm{t}$ 亿対し $12.6 \%$ を占めている。この比率は1972年に $8.5 \%, 1973$ 年に $9.9 \%$ で㘯るから，西部炭は現在急 速に開発されつつおることを示している。

1972年に和斿生産方式打よび炭鉱数としては坑内 掘りは58炭鉱で生産量は 9,342 千 $\mathrm{t}$, 露天掘りは50炭 鉱で生産量は 41,268 千 $\mathrm{t}$ であり, 露天掘生産比率は 
$81.5 \%$ を占めている。

これら西部諸州に打ける坑内掘りの 1 炭鉱当り平均 年間生産量は 16.1 万 $\mathrm{t}$ であり全アメリカ平均の 15.2 万 $\mathrm{t}$ を若干上超っているが，露天掘りでは 82.5 万 $\mathrm{t}$,

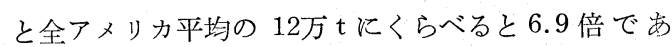
り, 西部は生産性の高い露天掘りの可能性地域である ことを示している。さらに 1975 年, 1980 年には年産 500 万 $\mathrm{t}$ 以上の大規模な露天掘炭鉱を石炭各社は計画 中である。

2.2 .3 所 見

西部炭田地帯に和ける最大の問題点は, 一部ワシン トン州を除き西海岸をでの内陸輸送距離が非常に長い ということであろう。すなわち比較的近いものでも $1,100 \mathrm{~km}$ 前後あり, 遠いものでは $1,600 \sim 2,200 \mathrm{~km}$ に達して扣り鉄道輸送費が非常に高くなるといらこと である。

第 2 には西部 9 州の埋蔵炭量のうち歴青炭は約 15 $\%$ ，また露天掘可能炭量のらち歴青炭はわずかに 4 \%であり，大半が覀歴青炭执よびかつ炭である。し たがって発熱量は亜歴青炭で 4,500〜 6, 000 cal，かつ 炭で 3,500 4,500 cal と低い。しかし硫黄分は $1 \%$ 以下である。そこで $6,000 \mathrm{cal}$ 以上のものを求めるな らば大部分が坑内採掘となり, 露天掘りに比べてコス 卜高となる。しかも内陸輸送費が高いのでコストの点 で問題があろら。

その他露天掘規制法案の問題，連邦政府所有鉱区に 対する鉱業権申請受付停止の問題, アメリカエネルギ 一自立計画の問題など，こんごのなりゆきに注目すべ き問題はあるが，一方ではアラスカ州を含め, 西部 9 州にはアメリカ埋蔵炭量の $66 \%$ が賦存して抒り, し か子その開発状況は1974年のアメリカ石炭生産量の 6 億 $\mathrm{t}$ に対してわずかに $12.6 \%$ の 7,600万 $\mathrm{t}$ であっ た。また採掘コストの安い露天掘可能炭量は約 300 億 $\mathrm{t}$ で, これはアメリカ露天掘可能炭量の約 $70 \%$ を占 めて扣る。現在は炭鉱近辺にある火力発電所の拡張計 画が各所で推進されて和り，大規模な石炭ガス化計画 と相俟って，露天掘り炭鈗を中心とした西部炭開発の テンポは加速される情勢にある。

したがって 6,000 cal 以上の石炭はコストの点で若 干問題はあるが, 5, 000 6, 000 cal のものは好条件の 露天掘可能炭量が相当量あるし, $5,000 \mathrm{cal}$ 以下のも のについては, 現在アメリカで研究されている品位向 上処理法, SRC, ガス化, 液化などの加工技術が開発 されるならば, 日本のエネルギー確保の上から, 長期 安定ソースとしての有力な候補地になるものと考えら
れる。

アラスカ州については，一部を除きほとんどが亜歴 青炭で，硫黄分は $0.5 \%$ 以下と少ないが，発熱量は 4, 000 5, 000cal と低い。したがってその分の輸送費 が割高となるほか，輸送中に自然発火を起す打とれが めるため, 原炭のままで日本に輸送することは難かし いと思われる。また人員の確保難, 人件費と物品費の 割高, 年間操業は可能とはいいながら冬期の厳しさな ぞの問題もある。しかしながらベルガ炭田のように海 岸より $32 \mathrm{~km}$ たらずの所に約 19 億 $\mathrm{t}$ の埋蔵炭量があ るといわれている石炭があり，しかも炭層は厚く，扣 扣むね平らで剥土量の少ない露天掘りに適した炭田が ある。しか子日本への輸送距離はオーストラリア，ア メリカ西部などに比べてはるかに近いので, これも西 部炭同様に加工技術が完成すればアラスカの石炭は日 本のエネルギー確保の上から重要な存在になるものと 考えられる。

\section{3. アフリカ（ボッワナ，モザンビーク）}

日本にとって将来の海外炭安定供給源の一つになり 得ると思われるアフリカのボッワナ共和国ならびにモ ザンビーク人民共和国について，一般炭に関する一般 情報の収集, 操業状況の調查和よび将来の開発可能性 検討資料の調査収集を行なった。

\subsection{1 ボツワナ共和国}

ボッワナ政府は工業化政策を進めており，鉱物およ び水資源の調査開発を重要視しておる。最近の約10年 間に探査の進展につれて相当の成果を収めている。

a) 炭量, 炭質

国土の $50 \%$ に和よぶ 26 万 $\mathrm{km}^{2}$ にわたるカール系 の賦存を確認して扣り, 現在も探査は進行中である。 1950１963年に拈けるボーリング調查によりモラプー ルとママブラの 2 炭田が発見された。

炭田の規模としてはモラプール 炭田は 90億 $\mathrm{t}$, マ マブラ炭田は 40億 $\mathrm{t}$ と報告されて招り，いずれも一 般炭と見られる。(原料炭は未発見)

現在稼行中のモラプール炭鉱 (1973年開坑) は坑内 採掘により採炭しているが，その可採炭量は 2,600 万 $\mathrm{t}$ である。炭質としては原炭で水分 $5.2 \%$, 灰分 14.9 $\%$, 揮発分 $23 \%$, 発熱量 $6,190 \mathrm{cal}$, 硫黄分 $1.8 \%$ な どである。

ママブラ炭田は 4 つのブロックに分かれて拈り，そ のらち中央部と南部の一部について調査が行なわれて いる。炭田の全ぼうはまだ明確にはなっていないが, 現在までの調査結果ではモラプール炭田と炭質的には ほとんど同じと考劣られている。ここでは河川水を利 


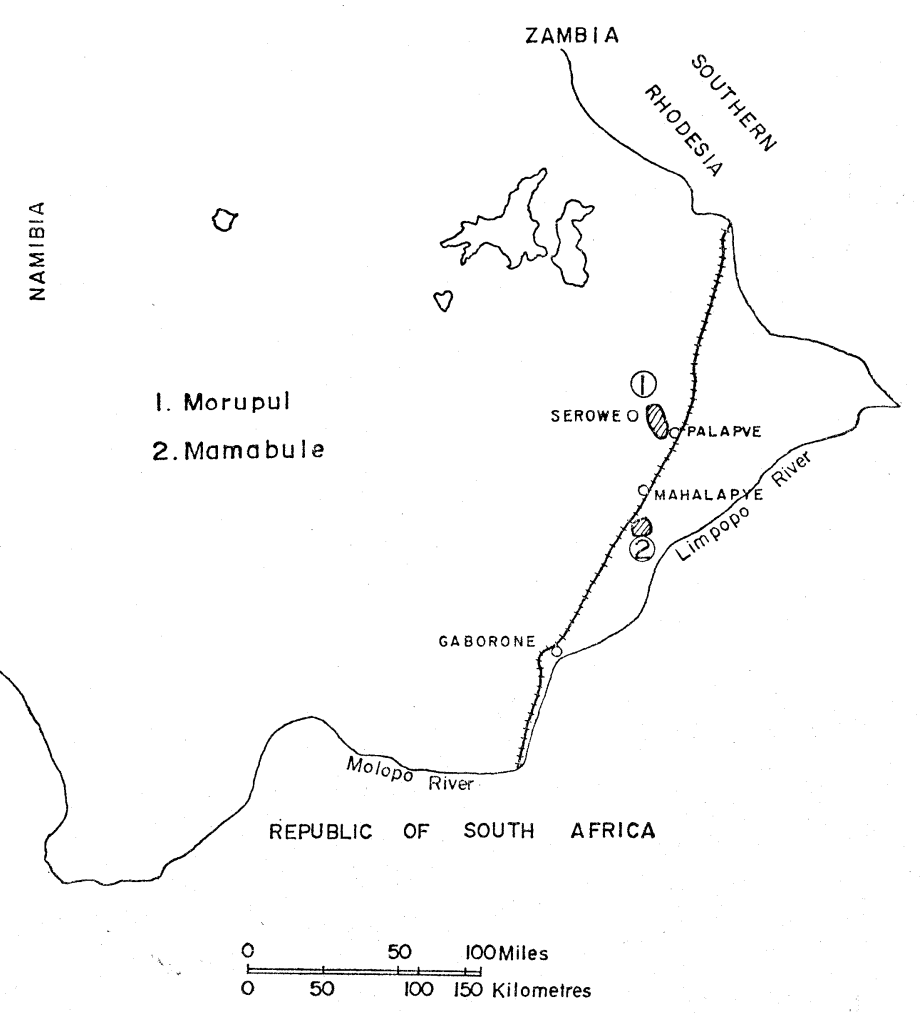

図 4 アフリカ ボッワナ共和国

用しての水洗も考光られ，鉄道からの距離も近いので 調査の進展につれて, そのポテンシャルは高まるもの と考光られ。

b) 鉱業政策

ボッワナ政府は化石然料の一つとして石炭の重要性 はこんご增大するものと考えて和り, その開発, 輸出 について意欲的に検討を進めている。最適生産規模に よる開発を実現するためには，大量の確定した需要の 存在することが前提条件となるので詳細な市場調査を 行なわなければならないが，原油価格との関連で石炭 販売の可能限界価格を仮定した試算によれば, 新しく 鉄道港湾を建設し，ウイルヒイス湾から EEC 向けに 輸出するのが最も有効であるとしている。

しかしながら政府担当官は日本の需要について非常 飞強い関心を持って和り,ボッワナ政府の日本も含め た市場開拓に積極的な姿勢がうかがわれた。

c) 所 見

こんごの探査の進展につれて, さらに石炭の埋蔵量 は增大し, 将来の有望な石炭資源の保有国になる可能 性を持っているものと考光られる。
現稼行炭鉱の炭層条件は良好で露天掘りによる大量 生産の可能性もある。しかしながら内陸国で立地条件 が悪く, 当面の輸入ソースとしての位置付けは低い。

炭田の規模, 条件から考光て原油の価格アップ, 一 般炭需要の增大, 供給源の分散などエネルギー経済の 情勢変化にともない, いずれは輸入ンースとして期待 されるものと考光られる。

\subsection{2 モザンビーク人民共和国}

1975年 6 月の独立後で日も浅く新政府による鉱業政 策などの基本的な資料はまだ公布されて和らない。い まだ日本との国交も樹立されていないが関係当局は好 意的であって, 現在稼行中のモアテイズ炭鉱の炭層, 採掘状況の調査ならびに資料収集を行ない，あわせて 新規開発区域（露天採掘）の調査，情報資料の収集を 実施した。またモアテイズ炭の積出港であるバイラ港 の設備, 石炭ストックヤードなどの現状を調査した。

a) モアテイズ炭鉱

モアテイズ炭田開発の歴史は古く約50年の稼行実績 をもっている。現在稼行中のものは CCM 社モアテ イズ炭鉱の 1 個所で, 坑内採掘により年産 50 60 万 


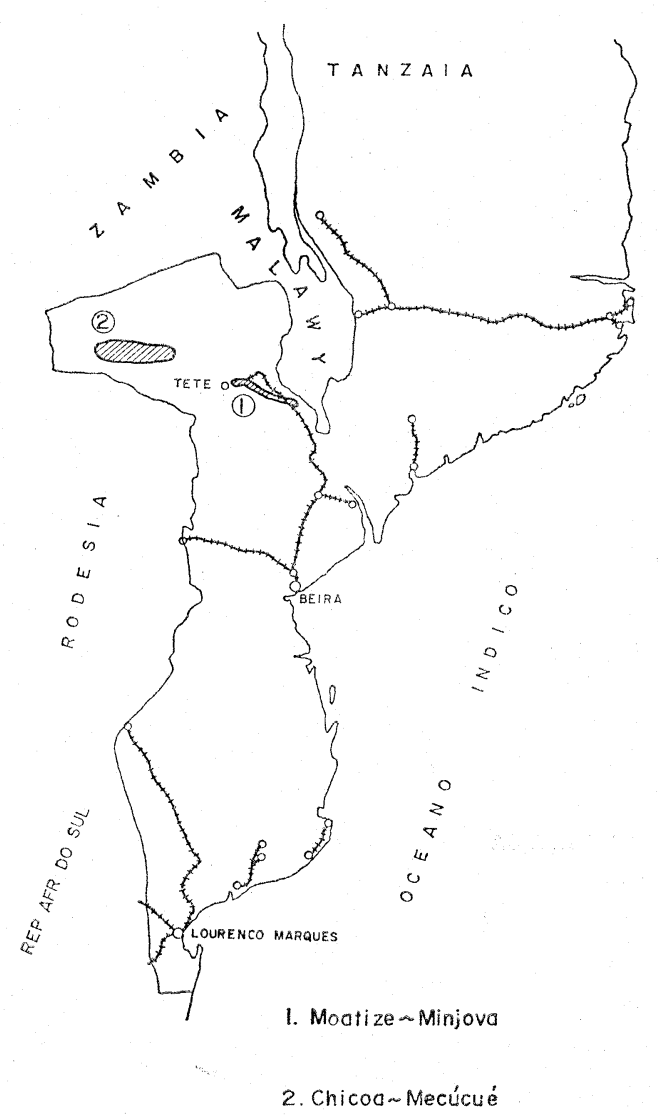

図 5 アフリカ モザンビーク人民共和国

$\mathrm{t}$ を生産して和り，原料炭50\%，一般炭 $50 \%$ となっ ている。原料炭は高灰分ではあるが低揮発分，強粘結 炭であり1969年以降その一部が日本に輸出されてい る。一般炭は国内消費和よび近隣アフリク諸国と EEC などに輸出されている。

モアテイズ炭鉱の増産計画は現在稼行している坑内 採掘の増産と新しい区域の露天採掘により年間生産量 として原料炭 250 万 $\mathrm{t}$, 一般炭50万 $\mathrm{t}$, 合計 300 万 $\mathrm{t}$ の 計画をもっている。

坑内採掘については，長年にわたる操業経験より地 質, 炭層和よび労働条件にマッチした採掘法を一応確 立しているものと考えられる。現状の改善余地はるち 論あるが, 1 坑口の出炭能力を日産 600〜800 t （原 炭）に抑芳その中で合理化を図り，増産は生産坑口 を増加することによって行なら方向を取るべきものと 考光る。年産 70 100万t の生産規模は現有の技術力 で十分と思われる。ガス，炭じん，自然発火など保安 上の配慮が必要であり, 保安規格の検討, 保安教育の 推進がいっそう望まれる。
露天採掘については, 現坑内採掘区域を除き鉱区内 の石炭賦存区域約 1,330 ha の中から比較的調查の実 施されている 3 つの区域 250 ha を露天掘りテストマ イニングの候補地として選定しフイジビリテイ，スタ デイ（F S）の準備作業としてボーリングを行なって いる。地表は平坦で捨場の確保, 運搬道路の建設など については好条件をもっているが, 炭層傾斜, 断層密 度，山丈炭丈比など露天採掘としての条件は良くな い。これから FS が実施される予定であるが，採掘場 設計には十分留意する必要があると思われる。生産規 模は数期に分け経済的に可能な最小規模でスタートし 操業経験そつかんでから段階的に生産量を拡大するこ とが望ましいと判断する。当面年産 240 万 (原炭) 程 度が計画の目途になるものとの感触を得た。

炭質については, 徒来坑内採掘による品質は未洗に よるもので交がー応の成果をあげて扣り，こんごも 坑内採掘については大きな変化はないものと考光られ る。露天採掘については選炭機の設備は必要でチパン ガ全層採掘に対する選炭性, 品質についてスタデイの 必要がある。鉱区南部に向って揮発分の増加傾向がみ られ, こんご調査密度を上げて実態を把握しながら炭 質の変化を加味した生産計画の立案へと進さことが望 まし。

\section{b ）バイラ港}

積出港バイラは河口港で現在 $25,000 \mathrm{DWT}$ 以下の 船舶でないと接岸荷役はできない。水路の浚渫は実施 されているものの現状水樑の維持では将来とも大型船 舶の荷役はできないるのと思わ机る。

港の能力改造に関する FS はモザンビーク政府の 要請により外国の専門コンサルタント会社が実施中で あった。

モアテイズ炭の積出し能力としては, ベルトコンベ アおよびリクレイミングの改造など一部の増強により 年間 $120 \sim 150$ 万 程度飞では期待でさるるのと考党 られる。

なお，モアテイズ炭鉱よりバイラ港をでの内陸輸送 $580 \mathrm{~km}$ の鉄道は現在で年間 60 万 $\mathrm{t}$ の能力を持って和 り,これの能力アップに関する FS b計画されてい る。路線の改修，ローリングストックの増強などによ り年間 200 万 までは可能と考觉られる。

c) 所 見

カボラバッサダムの完成により豊富な電力が 得ら れ, 南アフリカへの送電を始めようとしているので, 国内和よび近隣諸国に和ける一般炭需要の伸びは早急 に期待できないと考兄らる。モアテイズ炭鉱として 
は海外需要に重点を置いた計画を進めざるを得ない。 この場合に原料炭の産出割合は採班法, 選炭法により 変化するが大略 40〜60\% となり相当量の一般炭の販 路開拓が必要となる。日本としては距離的には離れて いるが，原料炭执よび一般炭のソースとして検討すべ きプロジェクトであると考党られる。

なお，今回調査できなかったチコア，メキュキュー 炭田については時期をみて調査が実施されることが望 ましい。

2.3 .3 所 見

ボッワナ，モザンビーク両国とも需要市場としての

日本に対し強い関心をもっている。

ボッワナ共和国のモラプール炭田は炭層, 炭質, 炭 量などからみて一般炭としてのポテンシャルは十分に あると考兄らるが内陸国であるため, 港湾までの輸 送距離などを考慮すると現時点においては海外への輸
出は難しい。しかし EC 諸国の輸出についてすでに 計画段階にあり政府担当官も日本の石炭需要について 強い関心をもっている。

またモザンビーク人民共和国は独立したばかりで日 本との国交が正常化していないが，原料炭需要国とし ての日本に大きな期待をしている。将来, 国交が正常 化した場合に未開発区域の調査を中心に採掘，選炭な ぞの技術交流を基盤とした開発輸入の対象国として大 いに期待される。

\section{4 インド}

インドの主要産炭地であるウェストベルガル，ビハ 一ル,オリッサ执よびマデイヤプラデシの 4 州の 6 炭 田, 13 炭鉱，2選炭工場とハルデイヤ（ウエストベン ガル州), パラデイブ (オリッサ州) の 2 港湾を調查 した。

インドの炭鉣はほとんどが国有化され，統括会社

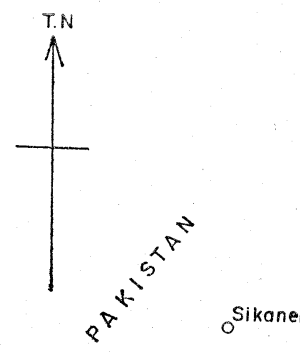

$\underset{0}{\text { Dolhi }}$

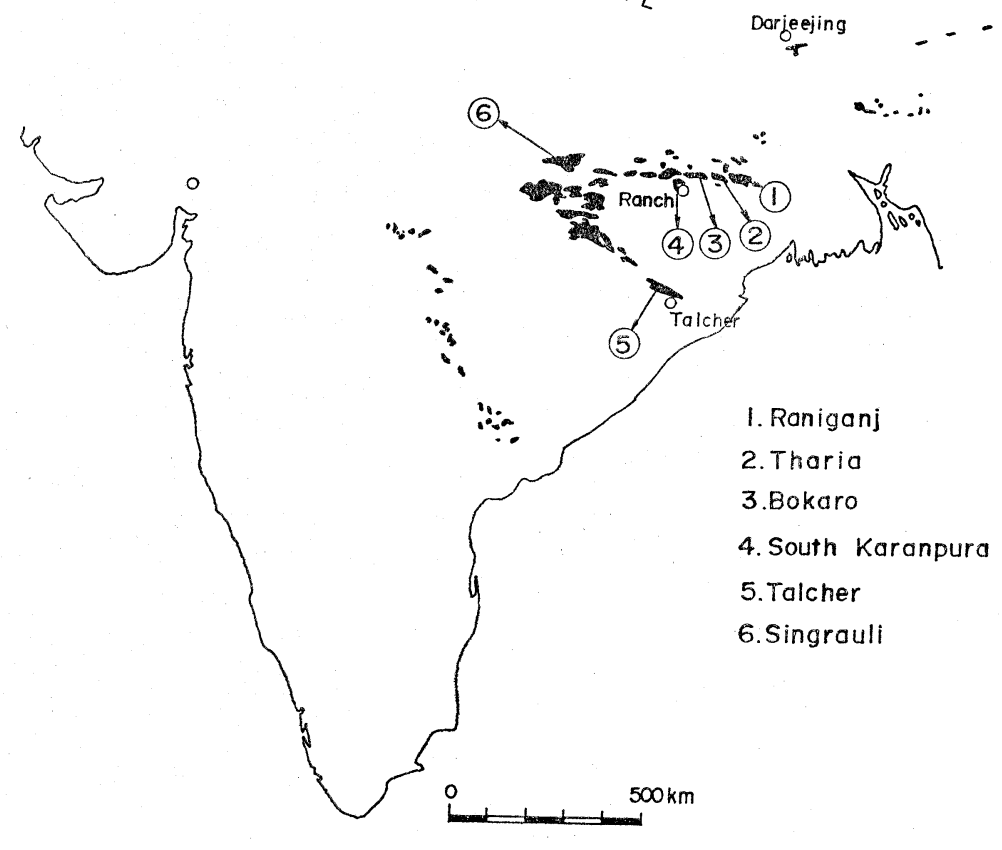

図6インド 
(CIL) の㻌下に专り, 開発対象としての有望な炭田 もすべて CIL の管轄下にある。またインド政府の経 済計画の中では石炭の海外輸出について, 現在のとこ ろバングラディシュ，ビルマなど近隣諸国以外は対象 とされていない。しかし日本，EC 諸国拉よび東南ア ジアなどを対象に石炭の輸出について非常に意欲的で あり，その可能性について検討中である。

インドの石炭は一般に灰分が $13 \sim 35 \%$ と多く, 発 熱量は 5,200 5, 900cal の低品位炭が多いが, 硫黄 分は $0.5 \sim 0.8 \%$ と比較的少ない。

一般的に良好な採掘条件と労務費が安いなどから生 産コストは低廉で方る。

2.4.1 埋蔵炭量, 炭質

確定炭量のみで粘結炭91億 $\mathrm{t}$, 非粘結炭 124 億 $\mathrm{t}$ で 推定, 予想炭量まで含めると粘結炭は 202億 $\mathrm{t}$, 非粘 結炭は 609億 $\mathrm{t}$ となり合計 811 億 $\mathrm{t}$ 亿達する膨大なる のである。このほかにから炭の確定炭量は 18 億 $\mathrm{t} て ゙$ これに推定，予想炭量を含めると21億 $\mathrm{t}$ となる。

ヒマラヤ, ブータン地域はインドで唯一の無煙炭産 地であるが炭層の厚さは $1 \mathrm{~m}$ 前後で炭田の 規模は小 さい。ダモダル溪谷地域はインドに和ける代表的な粘 結炭産出地域で同地域の総埋蔵炭量 520 億 $\mathrm{t}$ の添 40\% 飞当る約 200 億 $\mathrm{t}$ は粘結炭である。その他の地 域は局地的例外は除いてほとんぞ非粘結炭である。こ れらのゴンドワナ系の石炭は粘結炭, 非粘結炭に限ら ず灰分の多いのが特徴で良質のものでも10数\% 以上 の灰分を含有し，一般に 20４0％に達するものが多 い。

アッサム地域は古第 3 系の石炭で带歷青炭〜かつ岸 である。

2.4 .2 石炭の生産状況

1970年以降の石炭の生産実績䦽よび計画は表 2 亿示 すと拈りである。

\section{表 2 石炭生産の推移}

(単位 : 万 $t$ )

$\begin{array}{lrrr}\text { 年度 } & \text { 原料炭 } & \text { 一般炭 } & \text { 合 計 } \\ 1970 \text { (実績) } & 1,782 & 5,512 & 7,294 \\ 1971 \text { (") } & 1,675 & 5,566 & 7,241 \\ 1972 \text { (" ") } & 1,707 & 6,060 & 7,722 \\ 1973 \text { (" ") } & 1,577 & 6,240 & 7,817 \\ 1974 \text { (" ") } & 2,096 & 6,745 & 8,841 \\ 1975 \text { (見込) } & 2,200 & 7,600 & 9,800 \\ 1976 \text { (計画) } & 2,650 & 8,450 & 11,100 \\ 1977 \text { (" ) } & 2,820 & 9,530 & 12,350 \\ 1978 \text { (" ") } & 3,170 & 10,330 & 13,500\end{array}$

表 2 に見られるように炭鉱国有化（1971年に原料炭 産出炭鉱，1973年飞一般炭産出炭鉱がそれぞれ国有化 された。か）ら逐次，出産が增加していることは国有 化が一応の成果をあげているとい方よう。

州別ではビハール，ウエストベンガル和よびマデイ アプラデシの 3 州でインド生産量の 86 ～ $87 \%$ を占め て扣り, 原料炭生産はこの 3 州に限られている。

原料炭の生産比率は 22 24\% を占めるが，これは 弱粘結性, 高灰分, 低硫黄分などのため原料炭の混炭 用に用いられるものも含まれる。また灰分 $17 \%$ 以上 のものが $70 \%$ を占めて却り, 高灰分の原料炭が使用 されていることがわかる。

一般炭では $5,200 〜 5,900 \mathrm{cal}$ の範囲にはいるもの が主力となっている。

\section{4 .3 採掘方式}

露天掘りが約 $25 \%$, 坑内掘りが残り $75 \%$ となって いる。最近の傾向として露天掘りが増加しているが, これは国有化以後に重機類への投資が行なわれてきた ことによるものである。今後もシングラウリ炭田に大 規模な露天掘新鉱の計画が㐫るので露天掘比率は增加 するであろう。

坑内掘りでは立坑方式が圧倒的に多く斜坑方式は極 めてまれである。採炭方式はすべて柱房式であり, 発 破採炭と手積みによるものが最も一般的な方式であ る。長壁式は，いくつか試みられたことがあるようだ が現在は行なわれていない。このようにインドの炭鉱 では機械化は注とんど進んでいないのが現状である。 この理由としては低廉な労衝力が豊富であるから, 機 械の価格が貨金水準に比較して相対的に高価で㐫るこ と，新鋭機械を使いこなす技能学働者が少ないこと， 外貨事情から輸入機械が購入できないことなどによる ものである。

2.4 .4 所見

インド政府は原料炭の輸出については将来とも考兄 ていないが，一般炭の輸出については意欲的であり， 需要国 (日本) の意志表示 (炭種, 品位, 数量, 時期 など）があれば，それて合せてラニガンジとタルチヤ 一炭田を候補にあげて開発計画を考慮している。

炭質は可洗性の悪い低品位炭ではあるが，硫黄分は 少なく炭量は豊富である。地質構造は安定して拉り, また低廉な労働力も豊富であり出炭力はあるとみられ る。

したがって当面はインドを開発輸入の対象とするの には問題が票るが，長期的観点から注目すべき輸入y ースの一つと考光られる。特にラニガンジ, タルチヤ 
一両炭田を対象に開発輸入の候補地の一つとして, 調 查のフォローがなざ机るとともに日朴側からの参画の 体制についても検討它進められることが望ましい。

\section{3. 結 言}

以上 4 か国の一般炭の概要について述べたが，今回 の調査は最初の海外一般炭開発可能性調査であり, 本 調査はこんごる継続的に実施して海外炭の有望区域の 発見に努力したい。

な和今回の調査結果にもとずき将来の開発を進展せ しめるために昭和 51 年度より地質構造調查のためのボ ーリングに対する補助金の交付が決定し，最有力地区
への精査ボーリングの準備を進めている。 海外炭の開発に際しては, 当面コストの安い露天掘 り拉よび坑内掘りが対象となるのであるらが，坑内掘 りの場合には長年にわたり苛酷な条件を克服して研鑽 された日本の炭鉱技術, 特に高度な機械化採炭法の適 用により経済的な採掘が可能であると考兄られる。

このようにして日本の優秀な炭鉱技術を海外炭の開 発で積極的活用することは, 海外諸国との経済, 技 術協力を深めてゆく上にも極めて有効であると考它ら れる。

\title{
Present Status \& Future of Overseas Non-coking Coal
}

\author{
(Japan Overseas Coal Development Co., Ltd.)
}

SYNOPSIS:-In order to decrease the dependence on petroleum and to proceed with the various decentralization of energy resources, the necessity of intentional promotion of developing and importing of overseas excessive coal resources has increased.

Then, as a part of feasibility studies, we have made the gathering of general information, the study of mining operation, proposed development plans of coal mines and its feasibilities in four countries of Australia, U.S.A., South Africa and India, to grasp the present conditions and proposed plans in future, and to survey the sources of overseas non-coking coal for import to Japan.

All of the areas where we have surveyed this time have high potential as noncoking coal fields, so it is effective and indispensable to continue the detailed studies and to employ our skillful coal mining technique in the development and import of those resources. 